\title{
Property as Storytelling: Perspectives from Game Theory, Narrative Theory, Feminist Theory
}

\author{
Carol M. Rose*
}

\section{INTRODUCTION}

Many of our modern views about property, and indeed about political and economic matters generally, come from the works of seventeenth and eighteenth century theorists who hoped to find a firmly scientific basis for the study of "political economy." Their systematic approach suggests that these theorists' accounts of property might be purely analytic_-"synchronic" as the linguists call it. ${ }^{2}$ An account of this sort would treat the subject as if all its parts occur at once, in an interlocking whole whose various aspects can be inferred logically and verified empirically, without reference to origins or to transformative changes over time. ${ }^{3} \mathrm{On}$ such an account, one might indeed perceive that things change as time passes, but if one has a proper grip on the overall analytic framework, any changes would occur according to set patterns, so that future states are predictable from past states. This would be, more or less, a scientific

\footnotetext{
* Earlier versions of this paper were given at the 1988 Modern Language Association session on Interpreting Property, and at the University of Iowa Law School Faculty Seminar. For helpful comments and encouragement I also especially wish to thank Martha Fineman, as well as Mary Becker, Tom Grey, Janet Halley, Linda Hirshman, Martha Minow, Judith Resnik, and Cass Sunstein.

1. T. Hobbes, Leviathan, ch. 20, at 261 (C.B. McPherson ed. 1968) (1651) [hereinafter Hobbes]: "The skill of making, and maintaining Common-wealths, consisteth in certain rules, as doth Arithmetique and Geometry; not (as Tennis-play) on Practice onely"; see also J. Locke, Two Treatises of Government, editor's introduction at 104 (P. Laslett rev. ed. 1963) (3d ed. 1698) (hereinafter Locke) (editor quotes above sentence from Hobbes, describes Locke as influenced by Hobbes but more political in presentation of ideas); J. McCosh, The Scottish Philosophy, 2-3 (1875) (eighteenth century philosophic school hoped to inquire scientifically into human studies); A. Hirschman, The Passions and the Interests, 12-20 (1977) (seventeenth and eighteenth century insistence on taking "man as he really is," including vices, as basis of political thinking).

2. This use of "synchronic" derives from F. de Saussure, Course in General Linguistics 81 (C. Bally \& A. Sechehage ed., W. Baskin trans. 1959, from Saussure's 1916 Cours de linguistique générale); see also Goodrich, Law and Language: An Historical and Critical Introduction, 2 J.L. \& Soc'y 173, 177, 179-82 (1984) (describing Saussure's scientific linguistics, applications in other fields including law).

3. See F. de Saussure, supra note 2, at 90-95 (distinguishing synchronic from "diachronic" analysis dealing with changes over time); see also T. Eagleton, Literary Theory: An Introduction 110-111 (1983) (on Saussure and successors); Taylor, Interpretation and the Sciences of Man, in F. Dallmayr and T. A. McCarthy, Understanding and Social Inquiry 101, 104-106 (1977) (contrasting "scientific" approach to an interpretative one).
} 
approach: all changes in a given system are predictable from a proper synchronic analysis of the system itself."

But however much these early modern theorists hoped to ground political economy as a science, one notices that their discussions of property at some point take a striking turn towards a narrative or "diachronic" explanatory mode, ${ }^{b}$ treating property regimes as if they had origins and as if they developed over time. Locke is undoubtedly the most influential of the classic property theorists, ${ }^{6}$ and Locke used this narrative approach in his famous discussion of property in the Second Treatise of Government. Although the parts are somewhat scattered, the Treatise clearly unfolds a story line, beginning in a plenteous state of nature, carrying through the growing individual appropriation of goods, then proceeding to the development of a trading money economy, and culminating in the creation of government to safeguard property. ${ }^{7}$ Indeed Locke's choice of a narrative mode is all the more striking because he appears to have been indifferent to the factual accuracy of the story as a genuine history. ${ }^{\mathbf{2}}$

Almost a century later, William Blackstone launched into a quite similar pseudo-history in explaining property as an institution with an origin and evolution: he too described human beings as beginning in a state of plenty, gradually accumulating personal and landed property, and finally creating government and laws to protect property. ${ }^{-}$And in more recent days, the modern economist Harold Demsetz has chosen to illustrate his theory of property rights by reference to a narrative history of an evolving property regime among fur-hunting Indians on the American continent. ${ }^{10}$

Why have these theorists turned to story-telling to discuss property? Why have they chosen a narrative explanatory mode, which often diverges from scientific/predictive modes, and instead envisions events as unfolding

4. See T. Eagleton, supra note 3, at 111 (Saussure's successors treated changes over time as synchronic, systematic).

5. The distinction comes from Saussure, supra note 2, at 81 ; he contrasted diachronic to synchronic treatments at $90-95$, treating the former as accidental, unsystematic. See also. E.E. EvansPritchard, Social Anthropology, 60-61 (1951) (social science a synchronic study, history a diachronic one)

6. Locke continues to be central in modern discussions of property, and indeed has had something of a revival lately. See, e.g., R. Epstein, Takings 9-16 (1985); but see Grey, The Malthusian Constitution, 41 U. Miami L. Rev. 21, 31-32 (1986) (criticizing Epstein, contrasting to Locke and other classic writers); R. Nozick, Anarchy, State, and Utopia 174-82 (1974); Sanders, Justice and the Initial Acquisition of Property, 10 Harv. J. Law \& Pub. Pol'y 366 (1987) and comment thereto by Miller, Economic Efficiency and the Lockean Proviso, id. at 401; see also Rose, "Enough and As Good" of What?, 81 Nw. U.L. Rev. 417, 423-25, 430 (1987), and authorities cited therein.

7. Locke, $2 d$ Treatise $\$ \S 31,36-38,45-48,123-24$.

8. Locke, editor's introduction at 82, 89, 91 (Locke indifferent to political arguments based on history); see also id. at 111-112 (state of nature as historical state unproved, inferred from anthropological sources, analysis of relations of sovereigns).

9. 2 W. Blackstone, Commentaries on the Laws of England 3-9 (1766 \& reprint 1979) [hereinafter Blackstone].

10. Demsetz, Towards a Theory of Property Rights, 1967 Am. Econ. Rev. 347 (Papers \& Proceedings). 
in ways that, at least arguably, are only understandable after the fact ${ }^{11}$ That is the subject of this paper, or at least one of its subjects. The larger subject is the relation of property to story-telling generally: the reasons why in our general discussions of who has what, and how property gets distributed, we turn to narratives instead of looking exclusively to scientific or predictive analytic approaches. In treating that subject, the paper will borrow especially from game theory, narrative theory and feminist theory.

The first part of the paper will outline the classical theory of property, and in particular will identify the kinds of rational utility-maximizing preference orderings that this classical theory assumes in individuals. The next part of the paper will pose some practical difficulties for the classical theory; it will set out a series of thought experiments on preference orderings, and will particularly identify some quite familiar preference orderings that deviate from the classical model-preference patterns that are not "simply natural" or "just there," as a part of an assumed human nature of rational utility maximization, but that instead seem to require some post-hoc narrative explanation of how the preference-holders got that way.

The third part of the paper will begin to explain why a property regime needs the rhetorical mode of narrative and storytelling, a mode that seeks to account for events only after the fact, and that seems to assume a certain freedom among actors that is at least somewhat at odds with a logical predictive account. This part will use game theory to argue that the classic property theory itself has a kind of explanatory glitch: for property regimes to function, some of us have to have other-regarding preference orderings that the classical property theory would not predict, and can only explain post hoc, through a story.

The last part of the paper will offset game theory with feminist theory and the theory of narrative. Game theory suggests some reasons why the utility-maximizing preference orderings seem more "natural" than others-even though everyone knows that there are lots of non-utilitymaximizing preferences out there in the real world. This part of the paper will explore some ways that feminist theory and narrative theory use storytelling to counteract the impulses that we see in game theory: we use storytelling to break the spell of individual maximization, even among those more powerful than we; we tell tales to create a community in which cooperation is possible. Finally, the paper returns to the narrativity of classical property theory, and links the storytelling of classical property theory to a kind of moral discourse; it treats narrative as an exhortation to

11. Taylor, supra note 3 , at 129 (human events only understandable after the fact); $1 \mathrm{P}$. Ricoeur, Time and Narrative 147 (1984) (arguing that one cannot predict at the time of occurrence what will be considered important in future narrations); id. at 156-57 (discussing work of Lewis Mink, distinguishing post-hoc narrative explanation from ex-ante prediction of scientific methods). 
the listener to overcome a game-theoretic, self-interested "nature," and to follow instead the cooperative preference orderings that a property regime requires.

\section{The Preference Orderings in the Classical Analysis of PROPERTY}

We often think of property as some version of entitlement to things: I have a right to this thing or that. ${ }^{12}$ In a more sophisticated version of property, of course, we see property as a way of defining our relationships with other people. ${ }^{13}$ On such versions, my right to this thing or that isn't about controlling the "thing," so much as it is about my relationship with you, and with everybody else in the world: if I have a property right to this thing or that, I can keep you from exercising any control over it or having any access to it at all. That was Blackstone's benchmark for property: property was not just a "sole and despotic dominion," but it was a dominion that empowered the holder to the "total exclusion of the right of any other individual in the universe."14

In fact, that is the standard economic version of property: property as an institution revolves around the desire for resources themselves, but it also revolves around the desire to control others' access to those resources, at least when the resources are scarce. On this classical view, the institution of property mediates peoples' conflicting desires about resources, and it does so by allocating exclusive rights. If there were no property rights in the berry patch, all of us would just have to fight all the time for the berries. But instead, a property regime allocates this part of the patch to $\mathrm{X}$, and that part to $\mathrm{Y}$; and this (or any other) allocation gives each owner a sense of security, so that she invests in cultivation and tending the plants-which she won't do if she thinks she is going to wind up having to share the berries later with a lot of interloping loafers. ${ }^{15}$ Besides that, exclusive property rights identify who has what, and allow all of us owners to trade instead of fighting. As a result, everything gets more valuable. ${ }^{16}$ It all gets more valuable because the property regime encourages us to work, and then to trade the results of our work, instead of wasting time and effort in bickering and fighting.

So when we break down this very standard version of property, we find

12. Grey, The Disintegration of Property, 22 Nomos 69 (1980); see also B. Ackerman, Private Property and the Constitution 116-17 (1977).

13. Hohfeld, Some Fundamental Legal Conceptions as Applied in Judicial Reasoning, 23 Yale L.J. 16, 28-57 (reducing variety of entitlements to a set of "jural relations").

14. 2 Blackstone 2.

15. For a classic statement, see Bentham, Principles of the Civil Code, in Theory of Legislation 66-76 (R. Hildreth trans. 1975). See also 2 Blackstone 4 (property helps avoid "innumerable tumults" that occur when many vie for the same things).

16. R. Posner, Economic Analysis of Law 30-33 (notes that exclusive property rights enhance value, but also have some costs). 
several critical points. The first point is that desire - that is, a desire for resources-is at the center of the whole institution of property. ${ }^{17}$ The second point is that we need the capacity to shut out others from the resources that are the objects of our desire, at least when those objects become scarce. And the third point is that by allocating exclusive control of resources to individuals, a property regime winds up by satisfying even more desires, because it mediates conflicts between individuals and encourages everyone to work and trade instead of fighting, thus making possible an even greater satisfaction of desires. ${ }^{18}$

There is another element hidden in this analysis, though: it is the idea that we already know, at least roughly, how people are going to order their desires, or more technically, their preferences about themselves and others, and about their respective access to desired resources.

What is that understood ordering? Like many of our interesting ideas in this area, it comes to us from the seventeenth century, and most particularly from Hobbes first and later Locke. Hobbes' major point about human preferences is that individuals want to live. ${ }^{19}$ Our desire to stay alive is just there, omnipresent and undeniable; it needs no further explanation. When push comes to shove, Hobbes thought, we will prefer our own lives over other peoples', ${ }^{20}$ and by and large, we will also prefer our lives over highfalutin' causes, however noble. That is why in battle, for example, as Hobbes put it, "there is on one side, or both, a running away." "21

Locke's major addendum to this picture was to show the relevance of property to the desire to live. He pointed out that life depends on property, in a very primitive sense; if one cannot literally appropriate those berries and fruits, one will simply die. ${ }^{22}$

And so acquisitiveness, the desire to have property, is "just there" too, also universal and omnipresent; thus one can always predict a human desire to have things for one's self, or as they say more lately, the human

17. To be sure, some resources are a burden, like that horrid lamp that your Aunt Tilly gave you. Still, she wanted you to have it. And besides, if you have any sense, you can sell the stupid thing and buy something else that you do want.

18. See Rose, supra note 6, at 427-29 (comparing non-propertied society to society with property regime; latter has more activity, goods).

19. Hobbes, ch. 14, at 189.

20. Hobbes, ch. 13, at 184 (when two persons want the same thing and both cannot have it, they become enemies and "endeavour to destroy, or subdue one an other"). See also his defense of his view of the mutual enmity between persons: "Let [the doubter] consider with himselfe, when taking a journey, he armes himselfe . . ; when going to sleep, he locks his dores; when even in his house he locks his chests; . . . what opinion he has of his fellow subjects, when he rides armed; of his fellow Citizens, when he locks his dores; and of his children, and servants, when he locks his chests. Does he not there as much accuse mankind by his actions, as I do by my words?"

21. Hobbes, ch. 21; he also finds no new injustice in criminals' attempt to ward off the sovereign, "for they but defend their lives, which the Guilty man may as well do, as the Innocent." Id.

22. Locke, $2 \mathrm{~d}$ Treatise $\S 28$ (argues that if consent of all mankind were necessary for individual to propertize acorns or apples, "Man had starved, notwithstanding the Plenty God had given him"). 
propensity to be a self-interested rational utility maximizer. ${ }^{23}$ The propensity is just a kind of fact of life, and the eighteenth century political economists took it for granted, rejecting as unrealistic the earlier condemnations of acquisitiveness. They attempted instead to carry forward the new science of political economy on the firm ground of irreducible selfinterest, and indeed they toned down the language of "avarice" into that of the more benign "interest."

Indeed, if we do take these preferences for life and acquisition as givens, then economics can make a bid to be a kind of logical science in politics and law. With these preferences understood, we can sensibly talk about how the law gives people incentives to do this thing and that, and we can manipulate future welfare by institutionalizing the proper ex-ante approaches. ${ }^{25}$ Shifts of entitlements become predictable because we know how people order their preferences; with that knowledge, we can predict their responses and moves under different states of affairs.

That is what modern neoclassical economists do, more or less taking these utility-maximizing preference orderings for granted, and using them to perform some very powerful and sophisticated predictions of propertyrelated behavior under varying circumstances. They make predictions about the production or consumption shifts that follow from shifts of costs, and may predict, for example, a lowered provision of rental housing in the wake of added landlord repair costs. ${ }^{26}$ Underlying such predictions is an idea that people prefer more for themselves rather than less, and that this preference ordering is an irreducible fact that needs no further explanation-it is just there. ${ }^{27}$

Note, however, that if we do not have that starting point of a predictable set of preferences for "more" rather than "less," then the ways that people trade and otherwise shift their entitlements will be a little weird and unpredictable; and in talking about property, and about the ways

23. See, e.g., McChesney, Rent Extraction and Rent Creation in the Economic Theory of Regulation, $16 \mathrm{~J}$. Legal Stud. 101, 102-03 (1987) (treats political actors as self-interested utility maximizers).

24. A. Hirschman, The Passions and the Interests 54-65 (1977).

25. Alternatively, of course, we can collectively impoverish ourselves by giving people the wrong incentives. See, e.g., Easterbrook, The Supreme Court-Foreword: The Court and the Economic System, 98 Harv. L. Rev. 4, 10-13 (1984).

26. See, e.g., Meyers, The Covenant of Habitability and the American Law Institute, 27 Stan. L. Rev. 879 (1975) (predicting decrease in housing investment where landlord profits are lowered through costlier upkeep responsibilities); of. Kennedy, The Effect of the Warranty of Habitability on Low Income Housing: "Milking" and Class Violence, 15 Fla. St. U.L. Rev. 485, 506, 519 (1987) (effects indeterminate).

27. Economists do not generally purport to predict preferences for any particular resources, but rather treat those specific preferences as givens (or "exogenous"); see, e.g., Meyers, An Introduction to Environmental Thought: Some Sources and Some Criticisms, 50 Ind. L.J. 426, 450-52 (1975) (economics agnostic concerning values); Lee, Politics, Ideology and the Power of Choice, $74 \mathrm{Va} . \mathrm{L}$. Rev. 191, 193.94 (1988) (economic thinking suitable to any preference sets). This may change with an interest in "preference formation"; see, e.g., Sunstein, Legal Interference with Private Preferences, 53 U. Chi. L. Rev. 1129, 1145-58 (1986) and sources cited therein (examples of situation-related "adaptive preferences"). 
people deal with it, at least sometimes we may have to turn to post-hoc explanatory approaches to supplement our logical predictions. That is, we may only be able to understand property arrangements through narrative discourses like literature and history, discourses that construct a story of how things got to be that way-a story in which there were genuine choices along the way, and in which things were not really predictable in advance, and did not have to wind up the way they did. $^{28}$

\section{The Humdrum and the Weird; OR, Predictable and Unpredictable Preferences}

This part of the paper questions the idea that any given preference orderings are "just there," as they seem to be in the standard classical and neoclassical economic view. It suggests instead that even if one is quite sympathetic to the classical view of self-interest, there are a lot of leftover preference orderings that would not have been predicted, and that have to be explained in some way through an after-the-fact story. This part makes that point through a series of thought experiments on the ways that people order their preferences about their own and other people's access to resources.

These thought experiments present scenarios about preference orderings, in a situation where there are two people (you and I) and some Resource $\mathrm{X}$ that both of us desire. The scenarios presume five possible outcomes, to wit:

- I get a lot of $\mathrm{X}$, and so do you;

-I get pretty much $\mathrm{X}$ (where "pretty much" is something over onehalf of "a lot"), and so do you;

-I get a little $\mathrm{X}$, and so do you;

-I get a lot of $X$, and you get nothing; and

-I get nothing, and you get a lot of $X$.

Obviously these outcomes would not be exhaustive in the real world, but they are enough to work with for now. In each of the following scenarios, "I" order my preferences among these possible outcomes, beginning with the outcome that I desire most, and moving downward to the outcome that I desire least. Again, there is some mathematically large number of ways that people might line up these outcomes, but I have chosen six that are probably familiar to most readers, and have given them names so that they can be identified more easily:

Number 1: John Doe (JD). This perfectly ordinary person has the following ordering of preferences:

Choice \# 1: I get a lot, you get a lot.

2: I get a lot, you get zip.

28. See P. Ricoeur, supra note 11; Taylor, supra note 3, at 129. 
3: I get pretty much, you get pretty much.

4: I get a little, you get a little.

5: I get zip, you get a lot.

JD seems to be quite compatible with classical property thinking. His order of preferences is based on a kind of self-interest that is "just there." $\mathrm{He}$ is not mean, and is happy to have you get a lot of $\mathrm{X}$ where there is plenty to be had, but not if your share cuts into his. In general, he just prefers getting more over getting less, no matter what you get. ${ }^{29}$

Number 2: King of the Mountain (KOM). A somewhat more competitive type orders his preferences as follows:

Choice \# 1: I get a lot, you get zip.

2: I get a lot, you get a lot.

3: I get pretty much, you get pretty much.

4: I get a little, you get a little.

5: I get zip, you get a lot.

KOM is getting a bit slippery, from the point of view of the standard predicted preferences. He reverses John Doe's first and second preferences: he doesn't prefer the situation of maximum combined utility (both get a lot), but rather prefers the situation where he is the only winner. Still, economic prediction might be able to accommodate KOM; after all, $\mathrm{KOM}$ is just like JD insofar as he maximizes his own take, and his choices always put getting more over getting less. He just competes a bit more with the other guy. A little later, I will argue that with respect to property, JD and KOM are pretty much identical.

Number 3: Malice Aforethought (MA). This is a nastier character:

Choice \# 1: I get a lot, you get zip.

2: I get a little, you get a little.

3: I get pretty much, you get pretty much.

4: I get a lot, you get a lot.

5: I get zip, you get a lot.

MA is very slippery. MA would rather lose a great deal than have the other guy win; his preference ordering is based on keeping the other guy down. He is not looking very self-interested any more, at least in the usual sense. The reason is that he is "distracted" by interpersonal matters.

Number 4: Mom (or Good Citizen). Mom is a more comfortable figure, and orders her preferences this way:

Choice \# 1: I get a lot, you get a lot.

2: I get pretty much, you get pretty much.

3: I get zip, you get a lot.

4: I get a lot, you get zip (?).

29. Of course, even JD can become satiated with $\mathrm{X}$ after a while, if, for example, $\mathrm{X}$ is ice cream. But even if JD doesn't want a particular item for his own consumption, he does want it so that he can trade it to you, take the proceeds you give him, and go down to Bloomies to get something else that he does want. 
5: I get a little, you get a little (?).

Interestingly enough, Mom too is out of line for a prediction based on self-interest: her first choice is like JD's (both get a lot), but after that she prefers that both get a reasonably good deal, and thereafter she puts the other person first. Why would a self-interested utility maximizer do that? $\mathrm{S} /$ he wouldn't. Again, Mom seems to be distracted by interpersonal matters. But note, Mom's orderings choose highest joint utility first, the next highest next and so forth. As for the question marks by 4 and 5: if Mom gets a lot, maybe she can give you some; if she can't do that, she might prefer 5 to 4 .

Number 5: Portnoy's Mom (PM). She will be the first to tell you that her order of preference is:

Choice \# 1: I get zip, you get a lot.

2: I get a lot, you get a lot.

3: I get pretty much, you get pretty much.

4: I get a little, you get a little.

5: I get a lot, you get zip.

PM is even more out of line with a predicted preference ordering of selfinterested maximization. She would rather have the other person come in first-but she's not completely crazy, either, since her second choice is to do well herself, as long as the other guy does too.

Number 6: Hit Me. This is a kind of natural victim:

Choice \# 1: I get zip, you get a lot.

2: I get a little, you get a little.

3: I get pretty much, you get pretty much.

4: I get a lot, you get a lot.

5: I get a lot, you get zip.

This character is out of the economic predictor's ballpark. She is a mirror image of Malice Aforethought: She wants to lose, she wants to be beaten, preferably by somebody else.

I want to pause here a moment to reply to some objections. The first objection is that pleasure (or pain) about others' gains (or losses) are a part of a persons's preference orderings; for example, if I care about you, I always get a "lot" when you do. Now, this may be so, but it trivializes the whole idea of ordering preferences: getting a lot would always come first, by definition. ${ }^{30}$ So, to preserve the meaning of ordering preferences about one's own "take" in these two-party situations, I am using preference about one's self in a narrower (and I think more commonsensical) sense of what one gets of Resource $\mathrm{X}$.

The second and somewhat related objection is that a utilitarian/economic position is agnostic about preference orderings; economists can con-

30. For a similar view, see Farber \& Frickey, The Jurisprudence of Public Choice, 65 Tex. L. Rev. 873, 894 n. 129 (1987). 
struct a demand schedule for any ordering of preferences. Perhaps that is true, but if so, it means that economics loses its claim to predictive power; e.g., in a world of Hit Me's, we would see a higher demand for goods as costs rise, offsetting the self-interest of John Doe. ${ }^{31}$ An economist might be able to set a demand schedule if he knows the relative numbers of Hit Me's, JD's, etc., but that knowledge would have to come from some other source.

Now I want to return to the main argument. Which of our preference orderings can be predicted on the classical assumptions of self-interested maximization? John Doe certainly can be, and King of the Mountain too, if we assume that self interest simply means indifference about others. Both are maximizing their own "take," both consistently choosing more over less; and preference orderings like that are assumed to be "just there," without any need for further explanation.

But how about the others? However odd they are, and however small their numbers, characters with the offbeat and unpredicted preference orderings of Numbers 3 to 6 do indeed seem to be around too, at least in most people's repertoire of experience. How do we know that? Well, for one thing, we see these characters in actual narratives, both historical and fictional. Shakespeare and Gibbon, to take two illustrious examples, are all full of tales about Malice Aforethought and his vengeance and spite. ${ }^{32}$ Mom and the Good Citizen might be less dramatic, but they too are all over the place in heroic novels and tales; and according to feminist literature, the cooperative, helpful character is really quite common. ${ }^{33}$ Roth of course told the story of Portnoy's $\mathrm{Mom}^{\mathbf{3 4}}$ in a way that is apparently readily recognizable by a substantial segment of the population; and feminist literature has a good deal to say about $\mathrm{Hit} \mathrm{Me}$ and about victimization generally. ${ }^{35}$

31. Cf., e.g., Lee, supra note 27, at 193-94 (says that economics or public choice theory can accommodate any value set, but generally implies that as cost of activity rises, people will engage in it less).

32. For Shakespearian characters, see Iago and Shylock; these characters may have a "story," but that only reinforces the importance of narrative in understanding the MA preference set. As to Gibbon, see, e.g., chapter 4 in volume 1 of Decline and Fall of the Roman Empire, on "the Cruelty, Follies and Murder of Commodus"; or the description of the Emperor Caracalla, at 1, 113-119 (Modern Library ed., no date). For more current examples of this character, see the worries about computer "hackers" who introduce computer "viruses" for no apparent reason other than pride. E.g., "Innocence Periled in Computer Eden," N.Y. Times, Nov. 15, 1988, $§ 1$, at 31, col. 2 (virus implanter described as breaching trust, computer etiquette).

33. See C. Gilligan, In a Different Voice (1982). This character is fairly common in ordinary life as well. See, e.g., What's in a Neighborhood?, N.Y. Times, July 10, 1988, $\S 1$, at 20, col. 2 (local citizens, often women, may assist newcomers and organize neighborhood services). See also S. Kelman, Making Public Policy: A Hopeful View of American Government 255-65 (1987) (real-life examples of public spiritedness among political actors).

34. P. Roth, Portnoy's Complaint (1969).

35. See, e.g., Binder, Beyond Criticism, 55 U. Chi. L. Rev. 888, 908-10 (1988) (personality of passive dependence attributed to culture of instrumental rationality); $c f$. L. Gordon, Heroes of Their Own Lives; The Politics and History of Family Violence: Boston 1880-1960 (1988) (despite appearance of masochism, women attempted to protect selves and children from domestic violence). For a 
Those other characters certainly make themselves felt in the law as well. Here as in literature and history, some of the most interesting examples revolve about the Malice Aforethought character. In property law, there is a whole category of cases about people who build the so-called "spite fence"; their story revolves about a character who goes to considerable expense to wall in a neighbor's windows, or put up some repulsive object to ruin the neighbor's view of the sunset. ${ }^{36}$ An example from a few years ago involved a disappointed Vermont landowner, whose neighbors blocked his efforts to rezone his lot for motel use; he decided to use the property for a piggery instead. ${ }^{37}$ One needs to know the story, the narrative, to figure out how such people got that way.

Much sadder are the cases of $\mathrm{Hit} \mathrm{Me}$, the victims. The criminal law is now seeing persons who give away all they have, even their lives, and appear to defer consistently to some others in what seems to be a kind of pathology of other-regarding behavior. Perhaps such persons are not very common, and perhaps their motives are exceedingly complex, but their plight does seem to attract an extraordinary level of popular fascination, and perhaps self-comparison. ${ }^{38}$

The Good Citizen or Mom is another category that shows up constantly in law, and generally speaking, the law tries to encourage her cooperative behavior. The law allows people to set up all kinds of cooperative arrangements; people can form contracts and partnerships, hold joint bank accounts, and own property in various forms of common tenure. ${ }^{3 \theta}$ The law also polices cooperative arrangements and disfavors those in which one person seems to take advantage of another, even though the advantage-taking may fall within the formal terms of a given agreement. ${ }^{40}$ Moreover, while the law does not generally require that anyone assist another who is in trouble, it does recognize that some people will volunteer anyway, and protects those "Good Samaritans." Thus if John Doe's

related fictional treatment, see M. Atwood, The Handmaid's Tale (1985) (dystopia of subjugated women).

36. See, e.g., Erickson v. Hudson, 70 Wyo. 317, 249 P.2d 523 (1952) (after dispute over property line, defendant placed high fence 13 inches from neighbor's house, shutting off living room and bedroom windows, painted fence white on own side, creosote on neighbor's side); DeCecco v. Beach, 174 Conn. 29, 381 A.2d 543 (1977) (10-foot stockade placed in such a way as to destroy neighbor's view of river); see also Spite Fences and Spite Wells: Relevancy of Motive in the Relations of Adjoining Landowners, 26 Calif. L. Rev. 691 (1938).

37. With Motel Blocked, Developer Starts a Pig Farm, N.Y. Times, Dec. 19, 1982, § 1, at 42, col. 2.

38. See, e.g., Why Hedda Nussbaum So Compels the Public's Interest, N.Y. Times, Dec. 9, 1988, at B1, col. 2 (popular identification with battered woman witness in child homicide trial); on complex motivations, compare Binder, supra note 35 , with $\mathbf{L}$. Gordon, supra note 35 ; R. Gelles, Family Violence 108-25 (concerning why battered wives stay, tentatively concludes that major reason is lack of personal/economic/social service resources).

39. Our legal institutions, however, disfavor certain types of cooperation that victimize others, e.g. special calegories of crime for conspiracy, or antitrust sanctions against cooperative behavior to restrict supply, raise consumer prices.

40. See generally Rose, Crystals and Mud in Property Law, 40 Stan. L. Rev. 577, 597-601

(1988), and authorities cited therein (law unfriendly to deals leading to one-sided forfeiture). 
carelessness causes an accident, and Mom stops to assist the victim, tort law may make John Doe responsible for Mom as well as for the original victim, on the theory that he should have realized that she would try to help. ${ }^{41}$

The point of all this is that legal doctrines reflect the knowledge that these other preference orderings exist; certainly there is no monolithic legal expectation that everyone will behave as an individual self-interested utility maximizer. The further point is that all these offbeat preference orderings suggest an element of indeterminacy in the ways that people use property, trade it, transfer it. There is no single ordering of preferences in the real world, and everyone knows it; even supposing that most people are indeed like John Doe, the rest throw in a kind of chaos factor that may have odd effects in the world of property-holding. ${ }^{42}$

What does that mean? It means that even if we think the classical property view is generally true, we are going to have to make some allowances for oddities in the way people actually do order their preferences, at least some of the time. And that in turn means that the way we fix and trade entitlements is not going to be perfectly predictable, from a set of maximizing preferences that are just there. At least some of the time, in order to figure out how entitlements have shifted and settled as they have, we are going to have to have to explain things after the fact, post hoc-that is, we are going to have to tell a story.

\section{Narrativity and the Property Regime}

I want to go now to the point where the weakness of a single ordering of preferences is most telling. That point has to do with the very regime of property itself. But to get to that point, I have to begin with an explanation of a particular kind of property, that is, common property.

Common property is a kind of property system that often emerges when it is impractical or expensive to have individualized property in a given resource. For example, it might be awfully expensive to establish and police individual rights to fish in a large lake. At the same time, though, the fish are a finite resource, and it might be important to restrain the total "take," so that the fishery doesn't get overused or ruined, and so that the fish can regenerate. What our fishermen have to do, then, is to agree on some way that they can limit the times they fish, or the numbers they take, or the way they re-stock the lake-or do something else to protect the fish against decimation. ${ }^{43}$

Note that our fishermen now cannot follow the preference choice "I get

41. See, e.g., Prosser \& Keeton, The Law of Torts 307-08 (5th ed. 1984) (liability to rescuers).

42. J. Gleick, Chaos: Making a New Science (1987).

43. See Gordon, The Economic Theory of a Common-Property Resource: The Fishery, 62 J. Pol. Econ. 124 (1954); ^. McEvoy, The Fisherman's Problem 9-14 (1986). 
a lot, you get a lot," and just let all the fishermen take all the fish they want. That is the choice of plenty, and these fish are not infinitely plenteous, but are rather a limited resource. But the fishery resource is not easily divided up among the fishermen, either; it would be conserved and used most productively if all the parties were simply to exercise some forbearance. And so, they could be faced with what is conventionally called the "Prisoner's Dilemma": all parties have to give up something for the sake of a higher long-term collective total, but it is not at all clear that they will do so, especially since each has some individual motive to cheat on any cooperative arrangement. ${ }^{44}$

Now, this common-property problem creates a modification of the way we can picture the preference choices that were available to our earlier cast of characters. If we rule out the choice of Plenty (i.e., "I get a lot, you get a lot,"), the remaining options fall into the familiar Prisoner's Dilemma square:

\section{You cooperate}

I cooperate

I cheat
You cheat

(B) I get zip, you get lots. you get pretty much.

(C) I get lots, you get zip.
(D) I get little, you get little.

Of course, the best choice from the point of view of joint utility maximization is Box (A), where each fisherman cooperates and curtails some of his fishing for the sake of preserving the resource indefinitely for the whole group; that choice would mean that everyone would get pretty much over the long run, and the total fish taken would be maximized because the underlying resource would be able to renew itself. But for each fisherman, the individual's maximizing choice would be Box (C), in which he cheats while the others cooperate; thus he would prefer that all the others follow the rules and cooperate to curtail overfishing, while he "defects," or cheats, and takes all he can. But if each fisherman chooses this strategy of cheating, the whole system is driven toward Box (D), where all parties cheat, and the joint product winds up at a relatively puny level, because the fish are too depleted to regenerate. Thus the "cheating" choice can turn a renewable resource-a "positive-sum game" resource where there are gains from cooperation-into a wasting asset, a "zero-sum" resource in which all individual gains are at the expense of others, and in which the resource eventually depletes, to the ultimate detriment of all the players.

44. See McEvoy, supra note 43; R. Hardin, Collective Action 23-25 (1982); Hirschleifer, Evolutionary Models in Economics and Law: Cooperation Versus Conflict Strategies, 4 Res. L. \& Econ. 1 , 14 (1982); M. Ullmann-Margalit, The Emergence of Norms 18-21 (1977) (describing Prisoners' Dilemma); see also id. at 25-27 (describing application in large number situations). 
Now let us review the choices of our cast of characters: How would each character choose, if we rule out the option of Plenty (I get a lot, you get a lot)? And most important, would any of these characters be able to sustain a cooperative arrangement, and choose the optimal Box (A), where everyone acts to get "pretty much," but not the individual maximum?

First and most important, John Doe and King of the Mountain would not choose this cooperative Box (A). Where the option of Plenty is gone, they would have identical preference orderings. In a situation of finite or scarce resources, when we have to strike out the preference for everyone getting a lot, we see for both JD and KOM the following ordering:

1: C) I get lots, you get zip.

2: A) I get pretty much, you get pretty much.

3: D) I get little, you get little.

4: B) I get zip, you get lots.

When resources are limited, the cooperative management of common property is a second choice for both John Doe and King of the Mountain. Instead, in this situation of scarcity, they both have the same first choice: to take the mostest fustest. Hence the standard political economists' prediction, which is based on these characters, is what is called the Tragedy of the Commons: unless restrained by some outside compulsion, each tries to get the most for himself, and in the ensuing race, a resource that could be renewable is driven toward ruination instead. ${ }^{45}$

Malice Aforethought wouldn't put Box (A) first either. Striking the option of Plenty makes no difference to his first choice, which is (C) (I get lots, you get zip). In this he is like John Doe and King of the Mountain, even though his next choices would diverge from theirs. Mrs. Portnoy wouldn't choose box (A) either: her first choice remains (B) (I get zip, you get lots), which of course just encourages Malice Aforethought. And HitMe is like Portnoy's Mom in putting choice (B) first.

The heroine of the piece, then, is Mom (or the Good Citizen) who does not put her own well-being above yours, but is not a fool about needless self-sacrifice either: After the ruled-out choice of Plenty (I get a lot, you get a lot), her next-and now first-choice is the cooperative choice (A), (I get pretty much, you get pretty much). This is the most productive choice in a world where scarce resources have to be managed cooperatively; it is the choice that forbears from taking the largest individual portion and instead maximizes the joint product.

Now, here is the kicker. The larger implication of all this is that a

45. Hardin, The Tragedy of the Commons, 162 Science 1243 (1968); for examples concerning the environment, W. Ophuls, Ecology and the Politics of Scarcity 145-55 (1984) (predicts environmental ruin, as commons problem, in absence of coercive regulation); on housing, O. Newman, Defensible Space 3-8, 32-50 (1972) (relates high incidence of crime in highrise public housing projects to architectural "commons"-elevators, long corridors, large open spaces, etc.; contrasts with safer projects with space divided up, treated proprietarily). 
property regime generally, taken as an entire system, has the same structure as a common property. ${ }^{48}$ This is most notable at the formative stage. At the outset of private property, people have to cooperate to set up the system-they have to get themselves organized, go to the meetings, discuss the options, figure out who gets what and how the entitlements will be protected. ${ }^{47}$ Even if the property regime is just a matter of customary practices that develop over time, the participants have to cooperate to the extent of recognizing and abiding by the indicia of ownership that their customs set out. ${ }^{48}$ And indeed, even after a property regime is in place, people have to respect each others' individual entitlements out of cooperative impulses, because it is impossible to have a continuous system of policing and/or retaliation for cheating. Thus a property system depends on people not stealing, cheating and so forth, even when they have the chance-that is, all the participants, or at least a substantial number of them, have to cooperate to make a property regime work. ${ }^{49}$

A property regime, in short, presupposes a kind of character who is not predicted in the standard story about property. And that, I suggest, is why the classic theories of property turned to narrative at crucial moments, particularly in explaining the origin of property regimes, where the need for cooperation is most obvious: Their narrative stories allowed them to slide smoothly over the cooperative gap in their systematic analyses of selfinterest.

One can see the point in the various parts of Locke's story about property. He starts off with a tale of people in a state of nature, acquiring natural products like acorns and apples through the very labor of gathering them; $;^{30}$ and then realizing that wealth could be stored through the collection of durables (like nuts and little pieces of gold); $;^{51}$ and finally, growing nervous at the "very unsafe, very unsecure" enjoyment of property in the state of nature, and joining with others to establish the civil society that will protect everyone's hard-earned property. ${ }^{52}$

46. See Rose, supra note 6, at 438-39; see also Ramseyer, Water Law in Imperial Japan: Public Goods, Private Claims, and Legal Convergence, 18 J. Legal Stud. 51, at 75-76 (1989) (efficient legal orders, such as private property systems, are public goods with collective action problems, may not be solved).

47. See R. Hardin, supra note 44, at 34, 37 (individual motivations for contribution to ongoing collective action much weaker in explaining origins).

48. See examples in Rose, Possession as Origin of Property, 52 U. Chi. L. Rev. 73, 81-85 (1985).

49. See Rose, supra note 6, at 438-39. R. Axelrod, among others, has argued that the possibility of retaliation ("tit for tat") preserves a cooperative regime on a basis of self interest; see his book, The Evolution of Cooperation (1984). The difficulties are that (a) someone must make an initial cooperative move based on trust; (b) monitoring of the different parties' successive moves may be difficult, and (c) each party must continue to cooperate, disregarding the prospect of a last move on which a sheerly self-interested player would cheat (a prospect that would lead to cheating on the next-to-last move and so on back). For variations on these problems, see A. de Jasay, Social Contract, Free Ride: A Study of the Public Goods Problem 63-66 (1989).

50. Locke, Second Treatise $\S 28$.

51. Id. \$\$37, 46.

52. Id. $\$ 123$. 
Hold it right there: joining with others? Just how did they form that civil society and its government, anyway? Who put in the time and effort of schmoozing, and getting the special committees together, and hammering out the terms? Why didn't they all just loaf around, as John Doe would, choosing Box (C) in the hopes that other people would do all the organizing work? And if they did let George do it, who is this George character anyway? If there is a George, he looks an awful lot like Mom, or the Good Citizen-somebody who would be willing to do some work for the sake of the common good. ${ }^{\text {s3 }}$

Blackstone's story is a more connected narrative, but it slides over the point even more easily. After a long tale of the way in which people started to hold onto increasing numbers of objects for themselves, as they became more talented and numerous, ${ }^{54}$ he points out that the "earth would not produce her fruits in sufficient quantities, without the assistance of tillage: but who would be at the pains of tilling it, if another might watch an opportunity to seize upon and enjoy the product of his industry, art and labour?"ss Here is the very next sentence: "Necessity begat property, and in order to insure that property, recourse was had to civil society." ${ }^{\text {se }}$ And that's it.

Now wait a minute: If nobody would be at pains of tilling unless they could capture the rewards, why should they be at pains of setting up a civil society? Why don't Blackstone's characters sit around waiting for George too?

In short, there is a gap between the kind of self-interested individual who needs exclusive property to induce him to labor, and the kind of individual who has to be there to create, maintain, and protect a property regime. The existence of a property regime is not predictable from a starting point of rational self-interest; and consequently, from that perspective, property needs a tale, a story, a post-hoc explanation.

That, I think, is one reason Locke and Blackstone, and their modernday successors, are so fond of telling stories when they talk about the origin of property. ${ }^{87}$ It is the story that fills the gap in the classical theory, and, as Hayden White might put it, that makes property "plausible."'s8 Narrative gives us a smooth tale of property as an institution that could

53. Cf. R. Hardin, supra note 44 , at 36-37 (political entrepreneurship may explain some organizing activity, but weaker in explaining initial effort).

54. 2 Blackstone 2-7.

55. Id. at 8 .

56. Id.

57. See Demsetz, supra note 10; see also Anderson \& Hill, The Evolution of Property Rights: A Study of the American West, 18 J.L. \& Econ. 163 (1975) (evolution of property rights on example of Western land, livestock, water); Umbeck, A Theory of Contract Choice and the California Gold Rush, 20 J.L. \& Econ. 421 (1977) (same on example of gold miners).

58. H. White, The Content of the Form: Narrative Discourse and Historical Representation 9394, 193 (1987); see also P. Ricoeur, supra note 11, at 150 (conclusion of narration is acceptable rather than predictable). 
come about through time, effort, and above all through cooperative choices.

Cooperation, then, is a preference ordering that the classical property theorists weren't counting on in theory, but that they can't do without. And so they have to tell a story to explain it, and rely on our imaginative reconstruction from narrative to paint a plausible picture about how we got these property regimes in the first place.

\section{Reprise: The "NATURAL-NESS" OF SElf-INTEREST aNd THE "MORAL-NESS" OF THE PROPERTY STORY}

Quite aside from the thought experiments we have run through, and quite aside from the striking case of the cooperative preferences that we need for the institution of property itself, it should be pretty obvious that John Doe's self-interested preference ordering is only one among a number of options. In the real world, his orderings have to be explained too; they have a history too, and need a story just like anybody else's. The Critical Legal Studies movement has been around long enough to get across the idea that John Doe is just another story; it is instead the endless repetition of JD's "naturalness" that has made us think that his preferences are "just there," needing no further explanation or narration. ${ }^{59}$

Feminist theorists have made the point in another way: at least since Carol Gilligan, ${ }^{60}$ and really for some time before, we have realized that Mom or the Good Citizen-the caring, cooperative person generally-is just as much "there" as the indifferent non-cooperator, John Doe. Indeed, the feminist theorists have pointed out the importance of narrative in arriving at preference choices: Mom talks things over, and arrives at her preference orderings through discussion and negotiation ${ }^{\mathbf{6 1}}$-perhaps at least sometimes because she has little to begin with, and hence little capacity to retaliate against non-cooperators. Presumably, from Mom's (or Good Citizen George's) perspective, cooperation would be the predictable

59. See, e.g., M. Kelman, A Guide to Critical Legal Studies 270-71 (1987) (common language of private "rights" protects some widely divergent interests, ignores others); id. at 282 (liberal conceptions of rights and duties limit imaginative conception of needs); Kainen, Nineteenth Century Interpretations of the Federal Contract Clause: The Transformation from Vested to Substantive Rights against the State, 31 Buff. L. Rev. 381, 399-402, 451, 461 (argues that legal elite presented as "natural" some legal doctrines that undermined vested rights, in interest of making own choices on substantive "public policy"); Tushnet, An Essay on Rights, 62 Tex. L. Rev. 1363, 1392-93 (1984) (rights language a part of capitalist culture, limits discussion to negative individual rights).

60. C. Gilligan, supra note 33; see also Tronto, Beyond Gender Difference to a Theory of Care, 12 Signs 644, 649-51 (1987) (identifying ethic of care in variety of social groups).

61. See C. Gilligan, supra note 33, at 28-30 (describing communication, narrative as mode of arriving at moral decision; sees this as more typical of women); Friedman, Feminism and Modern Friendship: Dislocating the Community, 99 Ethics 275, 279-80 (1989) (on Gilligan and predecessors); West, Economic Man and Literary Woman: One Contrast, 39 Mercer L. Rev. 867, 873-74 (1988) (describes "literary woman," unlike "economic man," as using and hearing narrative to create intersubjective empathy); see also J. Freeman, The Politics of Women's Liberation 116-19 (1975) (feminist rap group tradition of "consciousness raising," change of attitude through shared narratives of experience). 
set of preferences, while John Doe's self-interest would be the oddity, and John Doe would have to be explained by some kind of story about how he got that way.

So why is cooperation the preference ordering that seems to need the story? There is, of course, the point that is made so tellingly by critical theory, and even more so by feminist theory: the dominant story-teller can make his position seem to be the natural one. ${ }^{62}$ It is not too hard to envision the bland John Doe (or perhaps the more competitive King of the Mountain) as the surrogate for the Liberal, the dominating storyteller and bete noire of the Crits; while Malice Aforethought could stand in for the Patriarch, another dominating storyteller and enemy of feminist theory. And one should note that John Doe, King of the Mountain, and Malice Aforethought all have a disturbing similarity in their patterns of preferences: where there is not enough to go around, where Plenty is ruled out as an option, each of these characters prefers as a first choice: "I get a lot, you get nothing." Perhaps this is why it is sometimes difficult to tell these characters apart.

But there is more to be said about these characters than their identity as a dominating group of storytellers. Consider Mom's big problem: suppose that she encounters John Doe, the blandest of these three noncooperating characters. However much she may prefer cooperative solutions, when she meets this non-cooperator, she has to choose between two roles she does not want. One of her choices is to be a Hit-Me victim, since her choice to cooperate would only meet John Doe's choice to cheat, which would put her in the worst of all possible positions. Her other choice is to mimic John Doe himself, by choosing mutual non-cooperation-but that is a role that she realizes would lead to a collective loss, which she also does not want. Thus unless she is dealing with another Mom, another cooperator, she is stuck with a choice between Boxes (B) or (D): the choice between cooperating and the great risk of domination, or of cheating and the certainty of the relative mutual impoverishment of "I get a little, you get a little."

And that, I would suggest, is a big reason why John Doe seems like nature, like something that is "just there," while Mom seems to need a narrative. John Doe chooses the safe route, the route that might lead to the jackpot if the opposite number is a cooperator/sucker, and that at least

62. See, e.g., West, Jurisprudence and Gender, 55 U. Chi. L. Rev. 1, $64-65$ (Hobbesian state of nature, liberal picture of equal and self-interesed individuals a male story, falsely told as if universally human); see also, e.g., Brennan \& Buchanan, Is Public Choice Immoral? The Case for the "Nobel" Lie, 74 Va. L. Rev. 179, 183-84 (1988) (describing feedback effect of self-interest hypotheses on behavior); Radin, Market-Inalienability, 100 Harv. L. Rev. 1849, 1877-81 (1987) (behavioral effects of rhetoric of commodification); Rose, Crystals and Mud in Property Law, supra note 40, at 610 (1988) (same); Ryan, Distrusting Economics, N.Y. Rev. Books, May 18, 1989, at 25, 26 (economics students disproportionately likely to behave selfishly in psychological testing). 
lets him get a little bit if the other guy is another noncooperative John Doe. $^{\text {B3 }}$

But Mom the cooperator takes risks for a common good. When it works, everyone is better off, but when it doesn't, she may lose horribly. And she makes you wonder, how did she get that way? Why didn't she take the safe route and cheat, like John Doe? Why does she hang in there, hoping the frog will become a prince? What gives her the nerve to take a risk that the other guy might be a cooperator too? More importantly, is it really a matter of her nerve at all, or only of having no alternatives - of using imagination in the face of hopelessness, of creativity when she has no leverage for retaliation? What's her story, anyway?

Thus we are back to storytelling-and not just the story about Mom, but also to the story that she can tell: her storytelling can both create a sense of commonality, and reorder her audience's ways of dealing with the world. According to the narrative theorists, the teller of the tales has a vision of some kind of community, even if it is only a community of two. ${ }^{64}$ The storyteller places herself with the audience experiencing the tale; she takes a clutch of occurrences and through narrative reveals them for her audience as actions, with beginnings, middles, and ends ${ }^{65}$-actions in which the audience can imagine themselves as common participants or common observers. When she tells us, "Here is what we (or they) did, and how we (or they) did it," she transforms events into our experienced or imagined actions, and in the process tells us who we are, as real or imaginable actors. Thus the storyteller, by structuring the audience's experience and imagination, helps to turn her audience into a moral community. ${ }^{68}$ Moreover, by structuring our experience of events, the storyteller in effect constructs our memories and consciousness, so that we can draw on this new stock to act in the future. In this sense, narratives change our minds, and give us an opportunity to reconsider and reorder our approach to events; we can recollect them as actions taken and not taken, and act differently in the future, instead of endlessly repeating some formulaic, repetitive, and predictable response, as rocks respond to gravity. ${ }^{67}$ Perhaps

63. JD may be using a maximin strategy, which involves making choices that minimize his maximum loss. This conservative strategy may be appropriate for zero sum games, but it is inappropriate in positive sum (i.e. cooperative) games such as the Prisoner's Dilemma. See M. Ullmann-Margalit, supra note 44 , at 20 n.1.

64. D. Carr, Time, Narrative and History, 61-62, 153-56 (1986).

65. Id., at 48-50.

66. Id. at 156-57; H. White, supra note 58 , at 25 (suggests, in form of rhetorical question, that narrative is "necessary for the establishment of that moral authority without which the notion of a specifically social reality would be impossible"); see also West, supra note 61, at 872 (narrative enables us to arrive at empathetic understanding of others); West, supra note 62 , at 65 (importance of telling stories to get across feminist viewpoint).

67. See Taylor, Interpretation and the Sciences of Man, in Understanding Social Inquiry (F. Dallmayr \& T. McCarthy ed. 1977) (distinguishing predictive science of repetitive events from posthoc, self-defining interpretation of human ones; latter characterizes events with a "conceptual innovation which in (urn alters human reality"); D. Carr, supra note 65 , at 60-62 (narrative gives means to 
this is what Mom is aiming at: Narrative theory coincides with feminist theory in suggesting that preference orderings don't just come out of nowhere; they may be constructs of narrative and negotiation, and may change over time, as we digest the stories of the places that our preferences have led us, or may lead us in the future, unless we act to lead them instead.

Thus as the feminist theorist Robin West has pointed out-though in somewhat different terms-narrative gives Mom a way to get John Doe to exercise a little imagination, and get him to take a chance on cooperating too, for the sake of a larger good. She can tell him a story, she can let him know that things don't have to be the way they are; she can put together a narrative to show how it feels to be in the other guy's shoes, and how it is that mutual trust and cooperative efforts are not only possible but preferable from everyone's point of view. ${ }^{68}$ In fact, there is even a story about this storytelling endeavor, in a way: it is the tale of Scheherazade. But even that is a particularly haunting story-of-storytelling, since the captive Scheherazade had no weapons but her wits, and her tale suggests that storytelling may begin in weakness, telling tales to power.

Perhaps now we can take another guess at why Locke and Blackstone and their successors have been telling those siren tales about property, too. Their theoretical self-interest had a fatal weakness too when it came to establishing a property regime. But if their tales could just get us John Does over the hump of our conservative, unimaginative, play-it-safe selfinterest, they might get us to establish property regimes; they might get us to recognize that if we all respect each others' claims, we can encourage everyone to expend labor on the resources of the world, and we all will be better off in the end. ${ }^{80}$

And maybe that is the real story about why they told those stories, and

act, dominate events); see also $1 \mathrm{P}$. Ricoeur, supra note 11 (criticizing purportedly predictive study of history as opposed to narrative).

68. West, supra note 61 , at $868-89,870$ (contrasting "economic man" who knows own preferences perfectly, with "literary woman" who learns of own preferences, empathy for others, through narrative); West, supra note 62, at 65 (points to need for feminist jurisprudence to tell stories to show importance of intimacy, empathetic values not just to individuals but to community and to "a well-led public life"). Sunstein, supra note 26, at 1169 , makes the point that we sometimes use legal means to enforce "preferences about preferences"; one might see narrative as a noncoercive means to talk people into these "meta-preferences" for cooperation.

69. Cf. West, supra note 62 , at 64 (equating story of state of nature as well as deliverance therefrom as "male" stories). On my own account, these stories are polar opposites, with the deliverance story entailing a cooperation quite at odds with the isolation and self-interest of the state of nature. This is not necessarily incompatible with West's view, since she sees masculine jurisprudence as preoccupied with the contradiction between isolation and community (i.e., isolation and deliverance could together comprise the same larger set of masculine jurisprudential obsessions)-as compared to feminist jurisprudence, which revolves about contradictions between intimacy and independence. $I d$. at 4$12,27-36,52-55$. West may also have a point insofar as the classical isolation/deliverance stories show a "manly" silence about the emotional content of cooperation. See infra text accompanying note 70; see also R. Axelrod, supra note 49 (treats cooperation as self-interest); of. Robert H. Frank, Passions Within Reason: The Strategic Role of the Emotions (1988) (arguing that emotion is essential to cooperation). 
why their successors continue to tell them. They may have been right or wrong in their argument that property improves the lot of humankind; and their smooth tales of property's cooperative origins may well have slighted the emotional context in which cooperation takes place. ${ }^{70}$ But those tales are moral ones all the same, just as much as Aesop's Fables, speaking to and constituting a kind of moral community, and urging that community to change its ways.

70. See West, supra note 62, at 65 ; R. Frank, supra note 69. 
Heinonline -- 2 Yale J.L. \& Human. 581990 